\title{
Errata
}

\section{Hidrodescloração Catalítica de Bifenilas Policloradas (PCBs)}

Luiz Américo da Silva do Vale

Dissertação, out./2008. Instituto de Química, Universidade de São Paulo, São Paulo.

I. Capítulo 1. Introdução. Na Seção 1.5.1. página $15,1^{\circ}$ parágrafo, $1^{\mathrm{a}}$ linha, onde se lê: "Neste caso, o efeito indutivo doador do grupo fenil estabiliza o íon arênio por efeito de ressonância." Entende-se que ambos os efeitos, indutivo e de ressonância, favoreçam a estabilização do íon arênio.

II. Capítulo 1. Introdução. Na Seção 1.5.1., página 15, último parágrafo, antepenúltima linha, onde se lê: "Considerando este fato, a reação de hidrodescloração ocorreria por transferência de hidreto, com a conseqüente formação da espécie $\mathrm{Cl}^{+}$." Entende-se que a espécie formada seja $\mathrm{Cl}^{-}$.

III. Capítulo 3. Na Seção 3.5.3., página 26 e seguintes, onde se lê "teórico" (em relação ao valor do ponto de fusão) entende-se "literatura".

IV. Capítulo 3. Na Seção 3.7., página 29, primeira frase do primeiro parágrafo, entende-se que seja indicada a seguinte referência: Doehlert, D.H.; Applied Statistics, 19, (1970), 231-239.

V. Capítulo 3. Na Seção 3.8., página 30, entende-se que a Tabela 3 tenha a seguinte nota de rodapé: "As variáveis reais foram codificadas de modo a corresponder aos vértices de um hexágono gerado por um simplex regular, com três repetições do ponto central".

VI. Capítulo 4. Na Seção 4.4., páginas 44, 46 e 47, onde se lê "brometo de alil(trifenil)fosfônio", entende-se "brometo de aril(trifenil)fosfônio".

VII. Capítulo 4. Na Seção 4.5., página 52, última linha onde se lê

“ $\rightarrow \mathrm{Pd}+2 \mathrm{H}_{2} \mathrm{O}+\mathrm{N}_{2}+$ Bifenilas ", entende-se

$" \rightarrow \mathrm{Pd}+2 \mathrm{H}_{2} \mathrm{O}+\mathrm{N}_{2}+$ Bifenilas $+\mathrm{HCl} "$.

VII. Capítulo 4. Na Seção 4.7., página 70, segundo parágrafo onde se lê "Considerando isso, percebe-se que o envenenamento do catalisador somente começou a influenciar a sua eficiência após três ciclos reacionais." Entende-se: "Considerando isso, percebe-se que a desativação do catalisador somente começou a influenciar a sua eficiência após três ciclos reacionais." 